\title{
EFFECTS OF TRANSACTION COSTS ON CHOICE OF SELLING POINT: A CASE OF SMALLHOLDER BANANA GROWERS IN THE GREAT LAKES REGION OF CENTRAL AFRICA
}

\author{
J.N. Jagwe* and C. Machethe**
}

\section{ABSTRACT}

This article examines the effects of transaction costs on the choice of marketing channel by smallholder banana producers (i.e. travel to the market to sell their produce versus selling at the farmgate). A probit analysis is used to identify the factors which determine the choice of a selling point. Variables capturing transaction costs are used in the analysis and these relate to searching for a trading partner, gathering information about the transaction, contracting, negotiating, monitoring and enforcing of contracts. The findings reveal that collective action, gender of household head, degree of dependence on the crop, geographical location and access to price information significantly affect the choice of selling point. This suggests that policies aimed at establishing market information systems, promotion of collective action among smallholder farmers, increased investment in rural infrastructure and achieving gender balance in trade are important.

Keywords: transaction costs, choice of selling point, farmgate, market/s, smallholder farmers, bananas, Great Lakes region

\section{INTRODUCTION}

This article examines the effects of transaction costs on the farmers' choice of selling point (i.e., either at the farmgate or travelling to the market). Smallholder farmers are constantly faced with a challenge of deciding at which point they should sell their commodities to maximise their profit. This decision may be affected by transport costs to the market, certainty of getting buyers, quantity of commodity to be sold, price expected, payment terms, capacity to store unpurchased commodities and nature of the commodity itself.

* Department of Agricultural Economics, Extension and Rural Development, University of Pretoria (LEVLO, 002, Pretoria, South Africa) c/o International Institute of Tropical Agriculture, P.O. Box 7878, Kampala, Uganda, Email: j.jagwe@iita-uganda.org

** Department of Agricultural Economics, Extension and Rural Development, University of Pretoria (LEVLO, 0002, Pretoria, South Africa),Email: charles.machethe@up.ac.za 
The choice of selling point is mainly determined by factors associated with transaction costs which by definition can be summarised as costs of looking for a trading partner, making and enforcing contracts (Delgado, 1999; Holloway et al., 2000). Transaction costs can be broadly categorised into (i) information and search costs; (ii) negotiation and contracting; and (iii) monitoring and enforcement costs. The first category involves gathering information about potential buyers of the product, price offers, delivery mode, terms of payment and, possibly, frequency of repeat transactions. The second category involves building consensus on the price, quantity, quality, terms of payment and mode of delivery. The third category involves making sure that what has been agreed upon in the contract is adhered to.

Nonetheless, transactions do take place when producers deal directly with consumers or indirectly through intermediaries, that is, economic agents who specialise in the activities of buying and selling the same products, commonly referred to as middlemen. The existence of friction in trade gives rise to the function of intermediation. Middlemen play the role of mediating between the seller of a product and its potential buyers. In instances where transactions are direct (i.e. without involving middlemen), the seller and buyer share the trade surplus. However, in instances where middlemen negotiate the trade, the middlemen share the surplus with the sellers and buyers. Economic literature rationalises the intermediation by arguing that intermediaries economise on the cost of transactions and information asymmetries (Chowdhury, 2002).

Though neo-classical economists essentially assume that information is perfect and costless, this assumption does not comply with reality, especially in developing countries (Stiglitz, 1988). Each step in a transaction is associated with a cost which generates a wedge between the buying and selling prices. One of the fundamental sources of transaction costs affecting both the smallholder farmers and intermediaries is the cost of obtaining information (Shepherd, 1997). Since information is neither perfect nor costless, this has important implications for contracts and transactions. This was pointed out by Coase (1937) and later expanded in Coase (1960), emphasising that market exchange is not costless. In developing countries, economic agents overcome the information problems and other setbacks of adverse selection and moral hazard through informal arrangements and institutions. The existence of intermediaries can, therefore, be viewed as one of the arrangements to overcome the problems of transaction costs and imperfect or costly information.

However, farmers often view middlemen as exploiters who offer them low prices and sell their products to buyers at higher prices, thereby bagging huge margins. Farmers have, therefore, made attempts to bypass middlemen and sell directly to buyers at the end of the supply chain, but this involves costs which are not anticipated by farmers. Middlemen have over time gained expertise in 
minimising transaction costs and, hence, there is a continuous debate about the gains and losses of selling through middlemen or directly.

Several studies have dwelt on empirically explaining the existence of middlemen in the context of developing countries by estimating their margins on each transaction. However, little attention has been accorded to explaining the role of transaction costs in the farmers' choice of either selling directly or through middlemen. Chowdhury (2002) assessed the impact of information cost and other transaction costs on rural producers of non-staples such as eggs, milk and chicken in Bangladesh. Nonetheless, the story could be different when handling a staple such as bananas, which, despite being highly perishable, are widely produced, sold and consumed in the Great Lakes region of Africa where transaction costs are high due to the weak physical and telecommunication infrastructure.

This study, therefore, seeks to understand how transaction costs influence the decisions of farmers on which channels to use when selling their products while taking into consideration the nature and economic importance of the product itself. The study aims at suggesting policy recommendations that will enhance the marketing of bananas in the Great Lakes region.

The rest of the article contains sections covering the crop in focus, the conceptual framework, the theoretical framework, the variables used and the results of the study. The article concludes with a summary of the key observations and policy recommendations.

\section{THE CROP IN FOCUS AND THE STUDY AREA}

Bananas are given the spotlight in this study due to their relatively high importance in the study area. The Great Lakes region of central Africa, specifically Rwanda, Burundi and the eastern parts of the Democratic Republic of Congo, has experienced political instability in the recent past. Some of the areas are still suffering sporadic occurrences of conflict and this has had negative impacts on the economic growth of the area. The importance of the banana crop (including plantain) in this area is relatively high in terms of income generation and food security. Bananas contribute 60 to 80 per cent of household incomes and constitute about 40 to 50 per cent of the agricultural production in the area (Spilsbury et al., 2004). Rwanda and Burundi are amongst the world's top 20 producers of bananas (including plantain), with annual production in 2008 estimated at 1.6 million and 2.65 million metric tonnes in Burundi and Rwanda, respectively (FAOSTAT, 2009).

\section{THE CONCEPTUAL FRAMEWORK}

Market participation not only implies travelling to the market, but includes selling output at the farmgate as well. Traders are, therefore, important partners to the 
farmers in the marketing of agricultural produce, especially where infrastructure is weak (Watanabe, 2006). Participation in the markets by smallholder farmers and traders is affected by government policies relating to infrastructure development, price controls and taxes (figure 1). Socio-economic factors, cultural factors and external factors such as political stability of the nation, natural disasters and calamities also affect market participation. These factors could have positive or negative effects, which could either improve or cause a decline in the welfare of the actors. The point of departure is that greater market participation of farmers and traders results in more commodities being traded and this may lead to more revenue being obtained by the actors. In the case of farmers, this becomes an incentive to increase production and, hence, a positive supply response is achieved.

This conceptual framework builds upon the World Bank's framework for promoting agricultural growth in sub Saharan Africa (World Bank, 2005; World Development Report, 2008). The premise behind this framework is that markets that function well are essential for stimulating productivity and profits which, in turn, stimulate agricultural growth and hence, reduce poverty. Building effective markets requires a supportive policy environment which ensures improvement of infrastructure, communications and removal of barriers which hamper growth of agri-businesses. The World Development Report (2008) emphasises that reducing transaction costs and risks in the marketing of food staples can promote faster growth and benefit the poor.

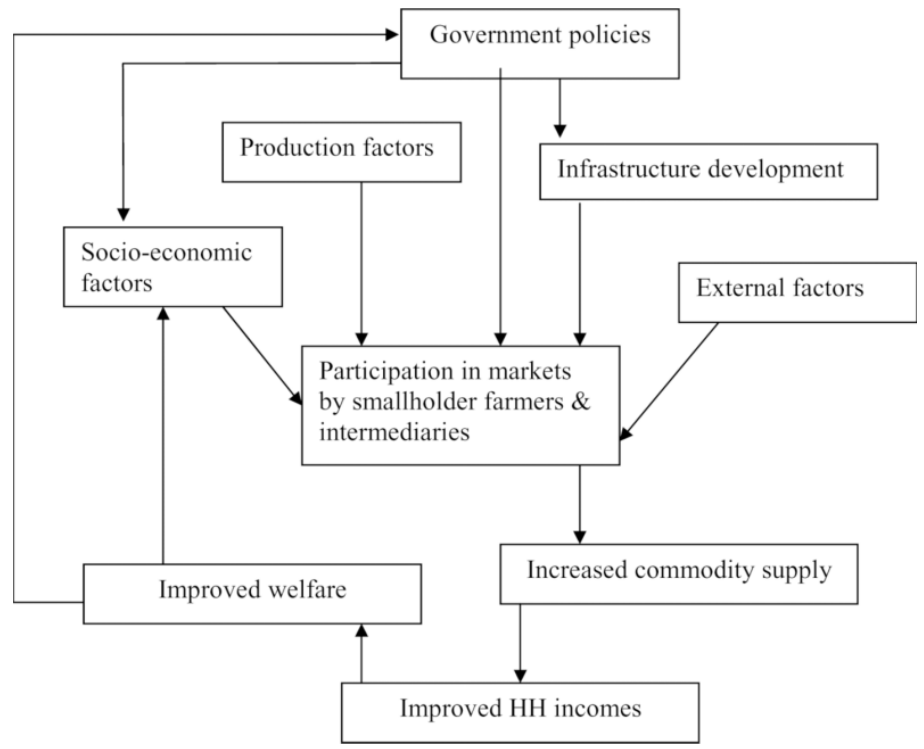

Figure 1: Factors affecting market participation of smallholder farmers and traders 
In this article, we postulate that banana producers make a discrete choice whether to sell at the farmgate or travel to the market. This decision is based on the margins obtainable while taking into consideration the costs involved. We assume that $\mathrm{P}_{\mathrm{prd}}$ is the producer price, which includes the cost of production plus the producer's margin, and $P_{m k t}$ is the average price at which the bananas would be sold if the farmer travelled to the market, while $P_{f g}$ is the price at which the bananas would be sold if the farmer sold to intermediaries at the farmgate. $T C_{f g}$ and $T C_{m k t}$ are transaction costs of selling bananas at the farmgate and the market, respectively.

Three scenarios (equations 1 to 3 ) are likely to guide the choice of a selling point, assuming that the farmers minimise costs and maximise profits.

$$
\begin{aligned}
& {\left[P_{m k t}-\left(P_{p r d}+T C_{m k t}\right)\right]>\left[P_{f g}-\left(P_{p r d}+T C_{f g}\right)\right]} \\
& {\left[P_{m k t}-\left(P_{p r d}+T C_{m k t}\right)\right]<\left[P_{f g}-\left(P_{p r d}+T C_{f g}\right)\right]} \\
& {\left[P_{m k t}-\left(P_{p r d}+T C_{m k t}\right)\right]=\left[P_{f g}-\left(P_{p r d}+T C_{f g}\right)\right]}
\end{aligned}
$$

Equation [1] suggests that farmers would opt to travel to the market to sell, while equation [2] suggests that farmers would opt to sell at the farmgate. Equation [3] suggests that farmers would be indifferent between travelling to the market and selling at the farmgate.

The choice of selling point $Y$ is, therefore, a function of the price offered at the market, the price offered at the farmgate, the respective transaction costs incurred, and other factors such as the institutional environment represented by $\mathrm{Z}$. This function is thus represented in equation [4]:

$$
Y=f\left(P_{m k t}, P_{f g}, T C_{m k t}, T C_{f g}, Z\right)
$$

We further postulate that scenario 3 may collapse into the other two scenarios, hence creating a situation where a discrete choice of the selling point has to be made. We adopt the situation that $Y=1$ represents scenario 1 , where travelling to the market to sell is opted for, while $\mathrm{Y}=0$ represents scenario 2, where selling at the farmgate is opted for.

Econometrically, the specification problem follows a latent regression model as shown in equation [5]:

$$
Y=f\left(P_{m k t}, P_{f g}, T C_{m k t}, T C_{f g}, Z\right)
$$


where $\mathrm{Y}^{*}$ is a latent variable that is unobserved. The dummy variable $\mathrm{Y}$ is what is observed and is defined by $\mathrm{Y}=1$, if $\mathrm{Y}^{*}>0$ and $\mathrm{Y}=0$, otherwise.

$y_{t}=\alpha_{0}+\sum_{p}^{p \max } \phi_{p} y_{(t-p)}+\sum_{q}^{q \max } \theta_{q} \varepsilon_{(t-q)}+\sum_{n}^{n \max } \eta_{n} D_{t}$

Furthermore, $\beta_{1}$ represents parameter estimates for the variables capturing the transaction costs and $\beta_{2}$ represents parameter estimates for variables capturing the other factors affecting the choice of a selling point (e.g., variables capturing the institutional environment).

The likelihood functions of this model are therefore written as:

$$
\begin{aligned}
& L\left(\beta_{1}, \sigma / Y_{i}, T C_{i},\right)=\prod \phi\left(-\beta_{1} T C\right) \prod\left[1-\phi\left(-\beta_{1} T C\right)\right] \\
& L\left(\beta_{2}, \sigma / Y_{i}, Z_{i},\right)=\prod \phi\left(-\beta_{2} Z\right) \prod\left[1-\phi\left(-\beta_{2} Z\right)\right]
\end{aligned}
$$

The marginal effects of this model are expressed as:

$$
\frac{\partial}{\partial T C_{i k}} \phi\left(T C_{i} \beta_{1}\right)=\phi\left(T C_{i} \beta_{1}\right) \beta_{k}
$$

$$
\frac{\partial}{\partial Z_{i k}} \phi\left(Z_{i} \beta_{2}\right)=\phi\left(Z_{i} \beta_{2}\right) \beta_{k}
$$

\section{THE DATA}

The data used in this study was gathered by the International Institute of Tropical Agriculture (IITA) in collaboration with the national agricultural research partners in the study area. These include INERA of the Democratic Republic of Congo, ISAR of Rwanda and ISABU/IRAZ of Burundi. The partners fall under the Consortium for the Improvement of Agriculture-based Livelihoods in Central Africa (CIALCA) which brings together three CGIAR centres operating in the study area. The CGIAR centres are IITA, Bioversity International and TSBF-CIAT, with funding support from the Belgium government through the DGDC project. The data was collected through a baseline survey conducted from December 2006 to March 2007. A total of 2666 households were interviewed.

The dependent variable (Y) is a binary, taking on the values 1 or 0 , if the common practice of the household is to (a) travel to the market with the commodity; 
or (b) sell the commodity at the farmgate, respectively. The independent variables range from those capturing transaction costs to those capturing the institutional environment within which the farmers operate. The variables capturing transaction costs include distances to the nearest market place and health centres, access to market information, membership of a market oriented group, and possession of means of transport. The variables capturing other factors affecting choice of a selling point include commodity price differences, degree of dependence on the product, scale of operation, family size, age of household head, gender of household head, access to credit, and asset holdings of the household. Table 1 presents a description of the variable names and their summary statistics.

Table 1: A description of the variables used

\begin{tabular}{|c|c|c|c|c|}
\hline Variable name & Description of variable & Mean & $\begin{array}{l}\text { Standard } \\
\text { deviation }\end{array}$ & $\begin{array}{l}\text { Percentage } \\
\text { for yes }=1\end{array}$ \\
\hline HHSELLINGMKT & $\begin{array}{l}\mathrm{HH} \text { mainly selling at the market } \\
(\text { yes }=1, \text { no }=0 \text { ) }\end{array}$ & & & $69.40 \%$ \\
\hline LANDSIZE & $\begin{array}{l}\text { Average land holdings (in hec- } \\
\text { tares) }\end{array}$ & 3.93 & 11.4 & \\
\hline HHSIZE & Average family size & 6.16 & 2.85 & \\
\hline AGE & $\begin{array}{l}\text { Average age of the } \mathrm{HH} \text { head (in } \\
\text { years) }\end{array}$ & 43.3 & 13.5 & \\
\hline EDUCATION & $\begin{array}{l}\text { Level of education of the } \mathrm{HH} \\
\text { head } \\
\text { (education level attained by scale } \\
1-6 \text { ) }\end{array}$ & 2.57 & 1.33 & \\
\hline HHHEAD_MALE & $\begin{array}{l}\text { HH headed by males (yes }=1 \text {, } \\
\text { no }=0 \text { ) }\end{array}$ & & & $80.96 \%$ \\
\hline CREDITUSE & $\begin{array}{l}\text { Used credit in ref. period (yes }= \\
1, \text { no }=0 \text { ) }\end{array}$ & & & $29.41 \%$ \\
\hline BICYCLE & $\begin{array}{l}\text { HH owning a bicycle (yes }=1 \text {, } \\
\text { no }=0 \text { ) }\end{array}$ & & & $32.48 \%$ \\
\hline RADIO & $\begin{array}{l}\mathrm{HH} \text { owning a radio (yes }=1, \text { no } \\
=0 \text { ) }\end{array}$ & & & $62.00 \%$ \\
\hline FGRPMEMBSHP & $\begin{array}{l}\mathrm{HH} \text { member belonging to a } \\
\text { farmer group (yes }=1, \text { no }=0 \text { ) }\end{array}$ & & & $29.64 \%$ \\
\hline COLLCTVMKTGRP & $\begin{array}{l}\mathrm{HH} \text { member belonging to a mar- } \\
\text { keting group (yes }=1, \mathrm{no}=0 \text { ) }\end{array}$ & & & $4.16 \%$ \\
\hline MKTDISTANCE & $\begin{array}{l}\text { Average distance to nearest } \\
\text { market (in KM) }\end{array}$ & 3.08 & 4.17 & \\
\hline
\end{tabular}




\begin{tabular}{|c|c|c|c|c|}
\hline HOSPDISTANCE & $\begin{array}{l}\text { Average distance to nearest } \\
\text { hospital }\end{array}$ & 11.59 & 10.08 & \\
\hline PXINFO_NONE & $\begin{array}{l}\mathrm{HH} \text { without access to price } \\
\text { information } \\
(\text { yes }=1, \text { no }=0)\end{array}$ & & & $6.18 \%$ \\
\hline $\begin{array}{l}\text { PXINFO_NEIGH- } \\
\text { BOUR }\end{array}$ & $\begin{array}{l}\text { Neighbours are the main source } \\
\text { of price info (yes }=1, \text { no }=0 \text { ) }\end{array}$ & & & $19.61 \%$ \\
\hline PXINFO_TRADERS & $\begin{array}{l}\text { Traders are the main source of } \\
\text { price info (yes }=1, \text { no }=0 \text { ) }\end{array}$ & & & $31.43 \%$ \\
\hline OFFFARMREV & $\begin{array}{l}\text { Average off-farm revenue (USD } \\
\text { per year) }\end{array}$ & 74.37 & 500.80 & \\
\hline BANAPRODN & $\begin{array}{l}\text { Banana production in ref. period } \\
\text { (in } \mathrm{KG} \text { ) }\end{array}$ & 1572 & 3060 & \\
\hline BANAPROPSOLD & $\begin{array}{l}\text { Proportion of bananas sold by } \\
\mathrm{HH} \text { in ref. period }\end{array}$ & & & $13.02 \%$ \\
\hline
\end{tabular}

Note: $\mathrm{HH}=$ Household; No. of observations, $n=2666$

The variable HHSELLINGMKT is the dependent variable which takes the values 1 or 0 , if households' common practice is to take produce for sale to the market or mostly sell their produce at the farmgate, respectively.

The independent variables capturing transaction costs include those relating to searching for trading partners and gathering of information about buyers and prices. Among these are the variables FGRPMEMBSHP and COLLCTVMKTGRP, which capture the involvement of household members in groups where information relating to selling their produce might be accessed. Negative signs are expected for the estimates of both of these variables because involvement in collective action is expected to assume a joint responsibility in marketing, which then relieves farmers from travelling to the market to sell their produce on an individual basis. These variables also capture the aspects of negotiating and contracting since a common voice tends to be more powerful than individual voices. Other variables related to information availability include; PXINFO_NONE, PXINFO_NEIGHBOUR and PXINFO_TRADERS. Negative signs are expected for the estimates of these variables on the basis that the greater the lack of information, the less likely it will be for farmers to travel to the market to sell their produce for fear of making losses. Ownership of means of transport and access to media are crucial in gathering information, hence the variables BICYCLE and RADIO are included in the model. Positive signs are expected for the estimates of these variables (Chowdhury, 2002).

Considering the aspect of negotiation and contracting, variables capturing the ability of the farmers to profitably engage with their trading partners are used. These include BANAPROPSOLD which captures the dependence of the household on the commodity. A positive sign would imply that households are 
less dependent on the commodity in terms of food for domestic consumption and, therefore, would be willing to sell much of it. The willingness to sell affects the farmers' negotiation position as well. The variables HHHEAD_MALE capturing gender concerns and EDUCATION are based on the assumption that maleheaded households and households headed by more educated people are better empowered to travel to the market and negotiate for better prices, hence positive signs are expected a priori. With regard to the monitoring and enforcement of contracts, variables such as MKTDISTANCE and HOSPDISTANCE do capture the degree of remoteness of the households which, in turn, has an implication on the monitoring and enforcement of contracts.

Other variables capturing the other factors that may have a direct or indirect influence on the choice of selling point of a household include LANDSIZE, HHSIZE, CREDITUSE, OFFFARMREV and BANAPRODN. These capture the characteristics of the household such as the size, land holdings, the asset base and the scale of operation which may have an influence on the choice of market outlet. The expected signs for the estimates of these variables are ambiguous since they are not directly linked to transaction costs.

\section{THE RESULTS AND DISCUSSIONS}

Table 2 shows the comparative statistics for households categorised by selling point.

Table 2: Comparative statistics for households categorised by selling point

\begin{tabular}{|l|c|l|l|l|l|}
\hline \multirow{2}{*}{ Variable description } & \multicolumn{4}{l|}{ Selling point } \\
\cline { 2 - 6 } & Market & Farmgate & Market & Farmgate & \\
\cline { 2 - 6 } & Obs & Obs & $\begin{array}{l}\text { Mean } \\
\text { (Std. Err) }\end{array}$ & $\begin{array}{l}\text { Mean } \\
\text { (Std. Err) }\end{array}$ & t-value \\
\hline${\text { Land holdings (hectares) }{ }^{+}}$ & 1635 & 720 & $\begin{array}{c}2.87 \\
(0.19)\end{array}$ & $\begin{array}{c}7.47 \\
(0.66)\end{array}$ & \begin{tabular}{l}
$8.72^{* *}$ \\
\hline Family size
\end{tabular} \\
& 1635 & 720 & $\begin{array}{c}6.23 \\
(0.07)\end{array}$ & $\begin{array}{c}6.13 \\
(0.11)\end{array}$ & -0.76 \\
\hline Age of household head (years) & 1614 & 712 & $\begin{array}{c}43.02 \\
(0.33)\end{array}$ & $\begin{array}{c}43.80 \\
(0.51)\end{array}$ & 1.29 \\
\hline $\begin{array}{l}\text { Distance to nearest market } \\
\text { (KM) }\end{array}$ & 1635 & 720 & $\begin{array}{c}3.24 \\
(0.11)\end{array}$ & $\begin{array}{c}2.99 \\
(0.13)\end{array}$ & -1.29 \\
\hline $\begin{array}{l}\text { Distance to nearest hospital } \\
\text { (KM) }\end{array}$ & 1635 & 720 & $\begin{array}{c}11.68 \\
(0.24)\end{array}$ & $\begin{array}{c}11.17 \\
(0.39)\end{array}$ & -1.13 \\
\hline
\end{tabular}




\begin{tabular}{|l|c|c|c|c|c|}
\hline $\begin{array}{l}\text { Selling price of cooking bananas } \\
(\mathrm{USD} \text { per kg) }\end{array}$ & 1635 & 720 & $\begin{array}{c}1.38 \\
(0.019)\end{array}$ & $\begin{array}{c}1.22 \\
(0.026)\end{array}$ & $-4.73^{* *}$ \\
\hline $\begin{array}{l}\text { Selling price of beer bananas } \\
(\mathrm{USD} \text { per kg) }\end{array}$ & 1635 & 720 & $\begin{array}{c}0.567 \\
(0.006)\end{array}$ & $\begin{array}{c}0.538 \\
(0.009)\end{array}$ & $-2.36^{* *}$ \\
\hline $\begin{array}{l}\text { Off-farm revenue (USD per } \\
\text { year) }\end{array}$ & 1635 & 720 & $\begin{array}{c}68.31 \\
(14.85)\end{array}$ & $\begin{array}{c}93.57 \\
(11.10)\end{array}$ & 1.07 \\
\hline $\begin{array}{l}\text { Banana production in ref. period } \\
(\mathrm{kg})\end{array}$ & 602 & 259 & $\begin{array}{c}1527 \\
(119.6)\end{array}$ & $\begin{array}{c}1859 \\
(205.2)\end{array}$ & 1.46 \\
\hline Banana sales in ref. period $(\mathrm{kg})$ & 602 & 259 & $\begin{array}{c}663.7 \\
(70.3)\end{array}$ & $\begin{array}{c}770.1 \\
(152.7)\end{array}$ & 0.72 \\
\hline $\begin{array}{l}\text { Proportion of bananas sold by } \\
\text { HH in ref. period }(\%)\end{array}$ & 1635 & 720 & $\begin{array}{c}14.01 \\
(0.007)\end{array}$ & $\begin{array}{c}14.66 \\
(0.011)\end{array}$ & 0.50 \\
\hline
\end{tabular}

Notes:

Standard errors are in parentheses

$\mathrm{H}_{0}$ : The means values are not significantly different.

** Significant at $p<0.05$ level implying reject $\mathrm{H}_{0}$

+ Wilcoxon-Mann-Whitney test performed

The two independent samples $t$-test was conducted on the continuous variables of the two categories of households (i.e., those mainly selling at the market and those mainly selling at the farmgate). The Wilcoxon-Mann-Whitney test was performed for variables that were not normally distributed. The null hypothesis tested was that there is no significant difference between the means of the two categories of households.

Table 2 shows a comparison between the farmers whose main selling point is the market and those who mainly sell their produce at the farmgate. The average land holding of farmers who mainly sell their produce at the market is much lower than the average landholdings of those farmers who mainly sell their produce at the farmgate (i.e. 2.87 ha and 7.47 ha, respectively). This observation may imply that resource poor farmers are more obliged to travel to the market to sell their produce as opposed to staying home and waiting for buyers. This result is similar to what Fafchamps and Hill (2005) observed when looking at coffee marketing in Uganda whereby wealthier farmers were less likely to sell at the market.

Significant differences were observed between the mean values of the selling prices of cooking bananas for the two household categories. This observation is very critical and may imply that households which commonly travel to the market do sell their commodities at much higher prices as compared to those which commonly sell at the farmgate. 
Significant differences in the mean values were also observed between the selling prices of beer bananas for the two household categories. This observation further affirms the previous deduction that households which commonly travel to the market do sell their commodities at much higher prices as compared to those which commonly sell at the farmgate.

The rest of the variables whose mean values were compared for the two household categories did not show any significant difference at the $p<0.05$ level. The sample is then further treated to a probit analysis to further establish the relationship between the dependent variable and the independent variables.

Table 3: The probit estimation results of the discrete choice between travelling to the market to sell versus selling at the farmgate

\begin{tabular}{|c|c|c|}
\hline Independent variable & Coefficient & Marginal effect \\
\hline LANDSIZE & $-0.005(0.0056)$ & $-0.002(0.002)$ \\
\hline HHSIZE & $0.018(0.0096)^{\star}$ & $0.0064(0.003)^{*}$ \\
\hline AGE & $0.009(0.003)^{\star * \star}$ & $0.003(0.0009)^{\star \star \star}$ \\
\hline EDUCATION & $0.026(0.037)$ & $0.0009(0.012)$ \\
\hline HHHEAD_MALE & $0.217(0.120)^{\star}$ & $0.0779633(0.04)^{\star}$ \\
\hline CREDITUSE & $0.105(0.098)$ & $0.036(0.033)$ \\
\hline BICYCLE & $-0.108(0.105)$ & $-0.0378873(0.037)$ \\
\hline RADIO & $0.047(0.106)$ & $0.016(0.0371)$ \\
\hline FGRPMEMBSHP & $-0.041(0.101)$ & $-0.014(0.035)$ \\
\hline COLLCTVMKTGGRP & $-0.192(0.249)$ & $-0.069(0.094)$ \\
\hline OFFFARMREV & $-0.00037(0.00017)^{\star \star \star}$ & $-0.00013(0.00006)^{\star \star \star}$ \\
\hline MKTDISTANCE & $-0.011(0.01)$ & $-0.004(0.003)$ \\
\hline HOSPDISTANCE & $0.009(0.004)^{\star \star \star}$ & $0.003(0.001)^{\star \star \star}$ \\
\hline PXINFO_NONE & $-1.022(0.259)^{\star * \star}$ & $-0.390(0.092)^{\star \star *}$ \\
\hline PXINFO_NEIGHBOUR & $-0.271(0.1233712)^{\star \star \star}$ & $-0.097(0.045)^{\star \star \star}$ \\
\hline PXINFO_TRADERS & $-0.564(0.108)^{\star \star \star}$ & $0.204(0.040)^{\star \star \star}$ \\
\hline BANAPROPSOLD & $0.004(0.129)$ & $0.0014(0.044)$ \\
\hline
\end{tabular}

\section{Notes:}

Dependent variable, $Y=1$, if selling at the market and 0 , if selling at the farmgate Standard errors are in parentheses ( ) *significant at 10\%, ${ }^{*}$ significant at $5 \%,{ }^{* * *}$ significant at $1 \%$

The results of the probit analysis are shown in table 3 and the discussion focuses on the variables which directly capture the effects of transaction costs on the discrete decision to sell at the market versus selling at the farmgate. 
In regard to gathering information about prices offered coupled with searching for potential trading partners, belonging to a farmer group or a collective marketing group decreases the probability of a household selling their produce directly at the market. This result, though not significant, is intuitive in the sense that farmers who belong to farming groups or marketing groups do sell their produce under such arrangements and hence they travel less to the market.

Furthermore, negative and statistically significant marginal effects are observed for the variables capturing sources of price information. Having absolutely no access to price information reduces the probability of a household selling their produce at the market. Intuitively, households very remotely located and with no access to price information whatsoever are less likely to travel to the market to sell their produce. They can only sell to those who manage to get to them. In such instances, farmers are likely to be more of price takers than price makers, especially when the commodity handled is highly perishable.

Furthermore, the significantly negative marginal effects observed for access to price information from neighbours implies that a situation where households only mainly access price information from village mates and neighbours reduces their chances of travelling to the market to sell their produce. A similar observation is made for those households mainly accessing price information from traders. The explanation for these observations is that households which do not have easy access to the market are prone to only obtaining information from neighbours, village mates and traders. In such a case, information may be distorted to the advantage of the other party, thereby discouraging farmers from endeavouring to travel to the market to sell their produce.

In terms of negotiations and contracting, the positive and statistically significantly marginal effects of HHHEAD_MALE and AGE imply that for a household head to be male and more advanced in age increases the probability of the household selling its produce at the market. This can be attributed to their ability to engage in negotiations and their experience in trade both of which are positively linked to age and gender.

The dependence on the product which is captured by OFFFARMREV and BANAPROPSOLD also affects the negotiations. The significantly negative marginal effects observed for the OFFFARMREV variable implies that the less the off-farm revenue, the higher the probability of selling produce at the market. Intuitively, households which are more dependent on farming endeavour to travel to the market in search for better prices. Similar observations were made by Chowdhury (2002) when looking at farmers in Bangladesh.

In regard to monitoring of the contracts and enforcement, variables such as MKTDISTANCE and HOSPDISTANCE were included in the analysis. The positive and significant marginal effect shown for HOSPDISTANCE implies 
that the more remotely located a household is, the greater the probability that this household's members will travel to the market to sell their commodities. The urgent need for cash revenue outweighs the opportunity cost of time especially for remotely placed households such that the members are willing to travel long distances to gain this revenue. This implication may be counter intuitive to the earlier observations by Fafchamps and Hill (2005) that shorter distances would favour the monitoring and enforcement of contracts, hence encouraging farmers to travel to the market.

The other factors included in the analysis were not significant except for the size of the household. The positive and significant marginal effect of this variable may imply that the bigger the family size, the greater the chances of travelling to the market to sell their produce. This could be attributed to the availability of household members to embark on the task which is relatively time consuming. Households with fewer members may incur a higher opportunity cost of their labour time.

\section{CONCLUSION AND POLICY RECOMMENDATIONS}

Indeed, transaction costs do have an influence on a household's choice of selling point. This influence is mostly related to searching for potential trading partners and gathering information about price offers, terms of payment, quality and quantity requirements of the buyers. This study has captured these aspects through a set of variables which relate to the transaction costs.

In regard to information access, the establishment of a market information system which provides timely and reliable information on prices, potential buyers and terms or conditions of purchase is highly recommended for the study area. Such systems have been established in the neighbouring Uganda and have registered remarkable improvement in information access by smallholder producers. Improved access to information empowers the smallholder farmers with knowledge and enables them to gain a better bargaining position, which in turn shields them from being exploited by intermediaries.

Collective action in farming and marketing activities should be supported and promoted in order to reduce transaction costs mainly associated with contracting and negotiating processes. Farming and marketing groups are able to assist farmers in finding buyers, negotiating with them for good prices, and in monitoring and enforcing the contracts made. The smallholder farmers when working jointly reduce the transaction costs immensely and may save a lot of time which they could have spent while working in isolation.

Policies which support increased investment in rural infrastructure should be developed. Rural infrastructure may refer to roads, electricity, telecommunication and market places. These play a crucial role in the exchange of goods and services. 
They facilitate information flow, negotiations, contract making processes as well as contract enforcement.

Finally, gender imbalances are significantly evident in agricultural produce marketing. The results of this study have confirmed that a household's choice of selling point is influenced by the gender of the household head. Policies aimed at supporting and protecting the vulnerable groups, especially female headed households, should be developed and implemented.

\section{REFERENCES}

Alene, A.D., Manyong, V.M., Omanya, G., Mignouna, H.D., Bokanga, M. and Odhiambo, G. 2008. Smallholder market participation under transactions costs: maize supply and fertilizer demand in Kenya. Food Policy 33(4):318-328.

Biglaiser, G. 1993. Middlemen as experts. Rand Journal of Economics 24(2):212-223.

Chowdhury, S.K. 2002. Access to information, transaction costs and marketing choice of rural households between middlemen and direct buyers in Bangladesh. Royal Economic Society Annual Conference, University of Warwik, Coventry, UK, August 2002. http://ideas.repec. org/p/ecj/ac2002/50.html (accessed 12 February 2008).

Coase, R.H. 1937. The nature of the firm. Economica 4(16):386-405.

Coase, R.H. 1960. The problem of social cost. Journal of Law and Economics 3(October):1-44.

Delgado, C. 1999. Sources of growth in smallholder agriculture in Sub Saharan Africa: The role of vertical integration of smallholders with processors and marketers of high value-added items. Agrekon 38(5): 165-189.

Fafchamps, M. and Hill, R.V. 2005. Selling at farmgate or travelling to market. American Journal of Agricultural Economics 87(3):717-734.

FAOSTAT. 2009. Food and Agriculture Organization; Online Statistical database http://faostat. fao.org/site/ (accessed 3 June 2008).

Gabre-Madhin E. 2001. Market institutions, transaction costs and social capital in the Ethiopian grain market. Research report 124, International Food Policy Research Institute, Washington, DC.

Goetz, S.J. 1992. A selectivity model of household food marketing behaviour in Sub-Saharan Africa. American Journal of Agricultural Economics 74(1992):444-452.

Holloway, G., Nicholson, C., Delgado, C., Staal, S. and Ehui, S. 2000. Agro-industrialization through institutional innovation, transaction costs, cooperatives and milk market development in the East African Highlands. Agricultural Economics 23:279-288.

Key, N., Sadoulet, E. and De Janvry, A. 2000. Transactions costs and agricultural household supply response. American Journal of Agricultural Economics 82(2000):245-259.

Kirsten J. and Vink, N. 2005. The economics of institutions: theory and applications to African agriculture. Course study material; Department of Agricultural Economics Extension and Rural Development, University of Pretoria, Pretoria.

Makhura, M., Kirsten, J. and Delgado, C. 2001. Transaction costs and smallholder participation in the maize market in the Northern Province of South Africa. Proceedings of the Seventh Eastern and Southern Africa Regional Conference, Pretoria, 11-15 February 2001. 
Shepherd, A. 1997. Market information services: Theory and practice. AGS Bulletin No. 125, Food and Agriculture Organization.

Spilsbury, J.D., Jagwe, J.N., Wanda, K., Nkuba, J. and Ferris, R.S.B. 2004. Evaluating the marketing opportunities for banana and its products in the principle banana growing countries of ASARECA, Kenya, Rwanda, Tanzania and Uganda. ASARECA / IITA Monograph 8, Ibadan, Nigeria.

Stiglitz J.E. 1988. Economic organisation, information and development, in Handbook of development economics, edited by H.Chenery and T.N. Srinivasan, (pp. 93-160). Amsterdam: Elsevier Science Publishers.

Watanabe, M. 2006. Middlemen: the visible market makers. http://ssrn.com/abstract=894866 (accessed 20 January 2008).

World Bank. 2005. Agriculture, rural development and pro-poor growth. Washington, DC: The World Bank.

World Development Report. 2008. Agriculture for development. Washington, DC: The World Bank. 